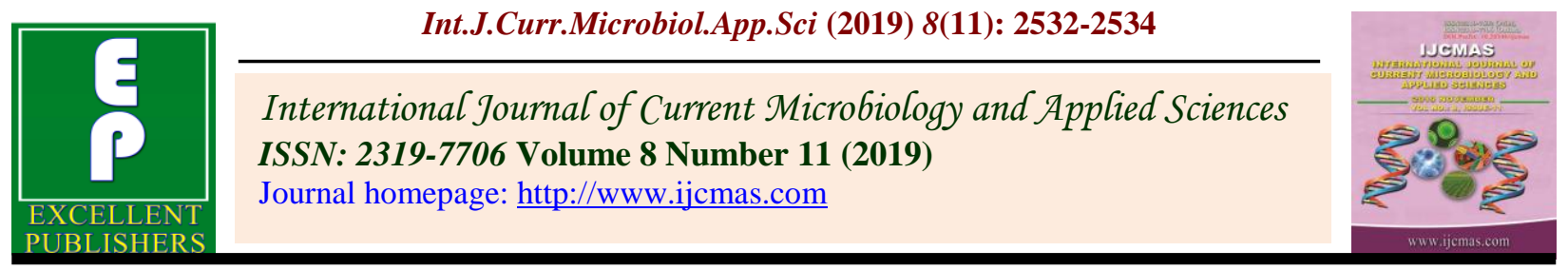

Short Communications

https://doi.org/10.20546/ijcmas.2019.811.292

\title{
Body Condition Scoring of Lactating Murrah Buffaloes Supplemented with Soybean Oil and Mustard Oil
}

\author{
Aayush Yadav ${ }^{*}$, G.P. Lakhani ${ }^{2}$, Biswajit Roy ${ }^{2}$, Sudipta Ghosh ${ }^{2}$ and Bhavna Aharwal ${ }^{2}$ \\ ${ }^{1}$ Department of Livestock Production and Management, College of Veterinary Science and \\ Animal Husbandry, CGKV, Anjora, Durg, C.G., India \\ ${ }^{2}$ Department of Livestock Production and Management, College of Veterinary Science and \\ Animal Husbandry, NDVSU, Jabalpur, M.P., India
}

*Corresponding author

\begin{abstract}
Keywords
Murrah buffalo, Supplementation,

Soybean oil,

Mustard oil, Body condition score

Article Info

Accepted:

26 October 2019

Available Online:

10 November 2019
\end{abstract}

A B S T R A C T

\section{Introduction}

The body condition score of an animal is the visual assessment of the amount of fat and muscle covering the bones of an animal, regardless of body size (Anonymous, 2019a) and is directly influenced by the energy balance (Anitha et al., 2011). Energy balance is the difference between energy consumed and energy expended. Early lactating dairy animals are said to be in negative energy balance as do not consume enough feed to meet the energy needs for maintenance and milk production. Under this state, the animals utilize body fat as an energy source and lose body condition in the process (Anonymous, 2019b). In this context, maximizing energy intake by increasing the energy density of diet is considered logical feeding strategy for early lactating dairy animals. Here, cereal grains play a valuable role as sources of energy in the ration of dairy animals. However, feeding excessive amount of grains is undesirable due to milk fat depression, reduced fibre digestibility and possible rumen acidosis. Alternatively, fat supplements can safely 
increase the ration energy density without disturbing the ruminal fermentation and improve the body condition score of animals (Boken et al., 2005). In India, soybean oil and mustard oil are cheap sources of fat supplements and traditionally used in field conditions. The effects of soybean oil and mustard oil on the body condition scoring of lactating Murrah buffaloes is scanty, based on which the present study was carried out.

\section{Materials and Methods}

A total of eighteen advance pregnant Murrah buffaloes from Livestock Farm, Adhartal, College of Veterinary Science \& A.H., NDVSU, Jabalpur (M.P.) were selected 21 days prepartum and maintained under semiintensive housing system. The animals were randomly divided in 3 groups of 6 each; CON (control; fed basal diet without supplementation), SBO (basal diet + soybean oil) and MO (basal diet + mustard oil). The oils were supplemented in concentrate@ 200 $\mathrm{ml} /$ animal/day upto 90 days postpartum.

All the experimental animals were fed according to their body weight, production and recommended nutrient requirements (ICAR, 2013). Water was made available to the animals round the clock and the daily routine managemental practices were followed in the dairy farm.

The body condition score (BCS) of buffaloes were observed at calving and then at monthly intervals till 90 days of lactation through visual observation and palpation to the 5 point scale with increments of 0.5 (Anitha et al., 2011). The data were statistically analysed using ANOVA, described by Snedecor and Cochran (1994) and means showing significant differences in the ANOVA table were compared using the Duncan's Multiple Range Test (Steeland Toorie, 1980).

\section{Results and Discussion}

The overall average BCS was $3.17 \pm 0.12$, $3.34 \pm 0.16$ and $3.30 \pm 0.15$ in $\mathrm{CON}, \mathrm{SBO}$ and MO, respectively (Table 1). There was no significant difference among the groups. The study reveals per cent improvement in body condition from calving to 3 months by 17.12 , 23.29 and 27.91 in $\mathrm{CON}, \mathrm{SBO}$ and $\mathrm{MO}$, respectively whereas; the per cent improvement in SBO and MO was 5.36 and 4.10 in comparison to $\mathrm{CON}$. Continuous increase in BCS was observed in all the groups throughout the study period.

Under conditions of similar DMI (kg/animal/day; $19.60 \pm 0.44,19.93 \pm 0.43$ and $19.41 \pm 0.48$ in CON, SBO and MO, respectively) and $\mathrm{BW}(\mathrm{kg} ; 529.72 \pm 6.95$, $540.75 \pm 10.40$ and $538.31 \pm 8.62$ in CON, SBO and MO, respectively) among the groups, the greater energy density of the soybean oil and mustard oil diet allowed a greater intake of energy to support a greater proportion of the milk produced compared with the buffaloes not supplemented.

The latter cows had to rely to a greater degree on body reserves for milk production and hence, had numerically lower body condition scores compared to the supplemented groups. The results are in accordance with the findings of Boken et al., (2005).

It is concluded that the supplementation of oils has insignificantly improved the body condition scoring in lactating Murrah buffaloes by keeping the animals in positive energy balance in comparison to $\mathrm{CON}$.

Soybean oil followed by mustard oil can be recommended during transition period and early lactation to get maximum benefits to the farmers by improving the body condition and ultimately the performances of animals. 


\begin{tabular}{|c|c|c|c|}
\hline \multicolumn{4}{|c|}{ Table.1 Average monthly body condition score (BCS; Mean \pm SE) of lactating Murrah } \\
buffaloes in different treatment groups
\end{tabular}

\section{References}

Anitha, A., Rao, K. S., Suresh, J., Moorthy, P. S. and Reddy, Y. K. (2011). A body condition score (BCS) system in Murrah buffaloes. Buffalo Bull. 30(1): 79-96.

Anonymous. (2019a). What is body condition scoring? https://bit.ly/2piTxqw. Accessed on 28 October, 2019.

Anonymous. (2019b). Body Condition Scoring and Energy Balance. https://bit.ly/2Pr7FZr. Accessed on 28 October, 2019.

Boken, S. L., Staples, C. R., Sollenberger, L. E., Jenkins, T. C. and Thatcher, W. W.
(2005). Effect of grazing and fat supplementation on production and reproduction of Holstein cows. J. Dairy Sci. 88(12): 4258-4272.

ICAR.(2013). Nutrient requirements of cattle and buffalo. Indian Council of Agriculture Research, New Delhi, India.

Snedecor, G. W. and Cochran, W. G. (1994). Statistical Methods, $7^{\text {th }}$ Edn., Oxford \& IBH Publishing Co., New Delhi, India.

Steel, R. G. D. and Torrie, J. H. (1980). Principles and procedures of statistics. A biometrical approach, $2^{\text {nd }}$ Edn.,McGraw Hill Book Co., New York, USA.

\section{How to cite this article:}

Aayush Yadav, G.P. Lakhani, Biswajit Roy, Sudipta Ghosh and Bhavna Aharwal. 2019. Body Condition Scoring of Lactating Murrah Buffaloes Supplemented with Soybean Oil and Mustard Oil.. Int.J.Curr.Microbiol.App.Sci. 8(11): 2532-2534. doi: https://doi.org/10.20546/ijcmas.2019.811.292 